\title{
Osteomyelitis and septic arthritis caused by Kingella kingae
}

\author{
JM DAVIS, MM PEEL \\ From the Microbiological Diagnostic Unit, University of Melbourne, Parkville, Victoria 3052, Australia
}

SUMMARY The clinical and bacteriological findings in two cases of osteomyelitis and one case of septic arthritis caused by Kingella kingae are presented. This appears to be the first report providing clear evidence for a pathogenic role for this species in bone and joint infections.

In 1968, Henriksen and Bøvre ${ }^{1}$ reported the results of their study on strains of bacteria representative of a group designated as Moraxella, new species 1 by Miss EO King and as group M-1 by later workers at the Center for Disease Control (CDC), Atlanta, USA. ${ }^{2}$ Although the group showed marked differences from Moraxella spp, the authors considered that the similarities shown were sufficient to warrant inclusion in the genus, and described a new species, Moraxella kingii, later corrected to Moraxella kingae. $^{3}$ In 1976, Henriksen and $\mathrm{Bøvre}^{4}$ presented genetic and phenotypic evidence to justify the transfer of Moraxella kingae to a new genus, Kingella.

Of the 75 isolates of Kingella kingae referred to CDC, 35 were from blood, 14 from throats and 21 from bone- or joint-associated sites. ${ }^{2}$ However, no information on the clinical significance of the isolates is recorded. We report here three isolations of the species, two from cases of osteomyelitis and one from a case of septic arthritis. This appears to be the first report in which a pathogenic role for Kingella kingae in bone and joint infections is specifically highlighted.

\section{Case reports}

\section{PATIENT 1}

A six-month-old baby boy was admitted to hospital on 18 May 1978 with a painless lump over the upper left portion of the sternum. Although the lump had gradually enlarged since it was first noticed one week before admission, the child had been well and afebrile. Examination revealed a hard non-fluctuant mass, measuring approximately two centimetres in diameter, over the manubriosternal junction. The lump appeared to be attached to deeper structures,

Accepted for publication 10 June 1981 not to the skin. An $x$-ray examination revealed rarefaction of the lower part of the manubrium, with a large, soft tissue swelling anterior to the sternum; there were no areas of rarefaction in the skull, pelvis or long bones. The day after admission, the lump was incised and surgically drained of approximately one millilitre of thick, yellow pus and the area of bone was curetted. Histological examination revealed the wall of an abscess. No organisms were seen in a Gram-stained smear of the pus, but culture of the specimen yielded a profuse, pure growth of Kingella kingae. The osteomyelitis was treated with cloxacillin ( $250 \mathrm{mg}$ six-hourly intravenously, then orally) and penicillin (125 mg six-hourly intravenously, then $200 \mathrm{mg}$ six-hourly intravenously, then $250 \mathrm{mg}$ sixhourly orally) then with penicillin only $(150 \mathrm{mg}$ six-hourly orally) when the isolate was found to be sensitive to penicillin. The treatment was continued for six weeks. A scanty growth of a Peptostreptococcus sp was obtained from a swab of the wound four days after the operation; otherwise the wound healed well and the infection responded satisfactorily to antibiotic treatment.

\section{PATIENT 2}

A two-year-old boy was admitted to hospital on 14 May 1979 with a history of a limp and pain in the left hip over the previous four weeks. An $x$-ray examination madealmost two weeks before admission had shown a lytic lesion in the metaphysis of the left upper femur and the child was referred to the hospital for further investigations. On admission, the child was afebrile and appeared well. An $x$-ray examination made the day after admission showed a moderate progression of the lytic lesion; this result, together with that of a bone scan, suggested a diagnosis of low-grade osteomyelitis. Three days after admission, curettage of the femoral neck was carried out. The histology of the curetted material 
was consistent with a diagnosis of chronic osteomyelitis. A Gram-stained smear of the material showed cellular debris and pus cells, but no organisms; culture yielded a scanty, pure growth of Kingella kingae. Antibiotic treatment with flucloxacillin and ampicillin (both $500 \mathrm{mg}$ six-hourly intravenously) was commenced after the operation; both antibiotics were taken orally after three days and the therapy was continued for six weeks. Apart from a brief, lowgrade pyrexia post-operatively, the patient's recovery was uneventful and he was discharged from hospital nine days after admission. An examination six weeks later showed a satisfactory response to the antibiotic treatment and he has required no further attention.

\section{PATIENT 3}

A 13-year-old boy was admitted to hospital on 14 January 1978 with a history of pain in the left hip over the previous 24 hours. The patient gave an uncertain story of a previous fall but had been otherwise well. On examination, the left hip was irritable with some restriction of the extremes of movement; by the next afternoon, the hip was too painful to move and the patient's temperature had risen to $38.6^{\circ} \mathrm{C}$. When purulent fluid was aspirated from the joint in theatre that day, an immediate arthrotomy was performed and more pus was obtained. No organisms were seen in a Gramstained smear of the pus. A light, pure growth of Kingella kingae was obtained from culture. The isolate was sensitive to penicillin so the initial antibiotic treatment of cloxacillin and ampicillin (both $500 \mathrm{mg}$ six-hourly intravenously) was changed to penicillin (one million units six-hourly intravenously). When the patient'scondition did not improve over the next few days, the penicillin dosage was doubled to two million units six-hourly intravenously and probenecid was given. The condition of the patient improved and he became afebrile within 24 hours. After eight days, he again became febrile and developed a skin rash. Although there was some evidence of a viral infection in the patient, the possibility of a hypersensitivity reaction to penicillin could not be excluded so tetracycline $(250 \mathrm{mg}$ six-hourly orally) was substituted for the penicillin treatment. The patient rapidly improved and was allowed home on crutches three weeks after admission. Tetracycline treatment was continued for two and a half weeks after discharge. When seen four months later, he had completely recovered.

BACTERIOLOGY

Cultures of pus and bone lesion material, collected before the start of antibiotic treatment, were incubated on horse blood agar at $35^{\circ} \mathrm{C}$ aerobically and anaerobically (patients 1 and 2) and at $37^{\circ} \mathrm{C}$ under $5 \% \quad \mathrm{CO}_{2}$ and anaerobically (patient 3 ). Cultures for detection of Haemophilus spp were included in all cases.

The colonial morphology and haemolytic properties of the three isolates were described from $5 \%$ (vol/vol) horse blood agar (HBA). Ability to grow anaerobically was tested on HBA and nutrient agar by incubation in an atmosphere of $90 \% \mathrm{H}_{2}$ and $10 \%$ $\mathrm{CO}_{2}$. Biochemical characteristics were determined mainly by the methods and media described by Cowan and Steel. ${ }^{5}$ Deamination of phenylalanine and growth in minimal medium with $\beta$-hydroxybutyrate as the sole carbon source were tested by methods described by Bøvre and Henriksen. ${ }^{6}$ Acid production from glucose, lactose, maltose and sucrose was determined in cystine trypticase agar medium (CTA Medium, BBL) containing $1 \%$ carbohydrate. Hugh and Leifson's OF medium, Thornley's arginine agar and all peptone-based liquid media were supplemented with $5 \%$ horse serum.

Tests for antimicrobial sensitivity were performed by the CDS method described by Bell. ${ }^{7}$

Colonies on HBA after 48 hours' incubation under $5 \% \mathrm{CO}_{2}$ at $35^{\circ} \mathrm{C}$ were gray, semi-opaque, low convex and smooth in consistency, with an entire edge. They were 1.5 to $2 \mathrm{~mm}$ in diameter and surrounded by a narrow zone of $\beta$-haemolysis. Slight pitting of the medium occurred around the colonies of strains from patients 2 and 3. Gram-stained smears of all isolates showed plump Gram-negative coccobacilli and bacilli in pairs and chains.

Optimal growth occurred at $35^{\circ} \mathrm{C}$ in an atmosphere containing $5 \% \quad \mathrm{CO}_{2}$; growth under anaerobic conditions was weaker and under aerobic conditions was delayed and poor. Colonies grew weakly and slowly on HBA at $22^{\circ} \mathrm{C}$. The presence of blood or serum promoted growth; no requirement for " $\mathrm{X}$ " or " $V$ " factors was demonstrated. No growth occurred on MacConkey agar. The organisms were nonmotile when grown at $37^{\circ} \mathrm{C}$ and $22^{\circ} \mathrm{C}$.

The results of biochemical tests performed on the isolates from patients 1 and 2 are shown in the Table. These results, together with the growth characteristics, microscopic morphology and motility results, agreed with those obtained for the holotype strain of Kingella kingae (Moraxella kingii NCTC 10529).

The isolates from patients 1 and 2 were sensitive to penicillin, ampicillin, cloxacillin, erythromycin, tetracycline, cotrimoxazole, gentamicin and chloramphenicol.

The isolate from patient 3 died before its characterisation could be completed. However, its growth characteristics, microscopic morphology, saccharolytic activity. positive oxidase and negative catalase 
Characteristics of the holotype strain of Kingella kingae (Moraxella kingii NCTC 10529) and of the isolates from patients 1 and 2

\begin{tabular}{|c|c|}
\hline $\begin{array}{l}\text { solates positive for: } \\
\text { Acid from glucose } \\
\text { Acid from maltose } \\
\text { Casein digestion } \\
\text { Cytochrome oxidase }\end{array}$ & $\begin{array}{l}\text { Fermentative reaction in } \\
\text { Hugh and Leifson's OF } \\
\text { medium } \\
\text { Phosphatase }\end{array}$ \\
\hline $\begin{array}{l}\text { Isolates negative for: } \\
\text { Acid from lactose } \\
\text { Acid from sucrose } \\
\text { Aesculin hydrolysis } \\
\text { Arginine hydrolysis } \\
\text { Catalase } \\
\text { Deoxyribonuclease } \\
\text { Digestion of inspissated serum } \\
\text { Gelatin liquefaction } \\
\text { Growth on } \beta \text {-hydroxybutyrate } \\
\text { Growth on Simmons' citrate agar } \\
\text { Hydrogen sulphide production in } \\
\text { TSI* }\end{array}$ & $\begin{array}{l}\text { Indole production } \dagger \\
\text { Lysine decarboxylase } \\
\text { Nitrate reduction } \\
\text { Opalescence on lecithovitellin } \\
\text { agar } \\
\text { Ornithine decarboxylase } \\
\text { Phenylalanine deaminase } \\
\text { Starch hydrolysis } \\
\text { Tween } 80 \text { hydrolysis } \\
\text { Urease } \\
\beta \text {-galactosidase }\end{array}$ \\
\hline
\end{tabular}

*TSI = triple sugar iron agar.

†Using Kovács' reagent.

†Isolate from patient 1, negative; holotype strain and isolate from patient 2 , trace.

and nitrate reactions allowed it to be identified as Kingella kingae.

\section{Discussion}

Henriksen considers that the natural habitat of Kingella kingae is the mucous membranes of the upper respiratory tract where it exists as a "comparatively harmless parasite." 8 It has been incriminated in two cases of infective endocarditis. ${ }^{9} 10$ It has also been reported from blood cultures, boneor joint-associated sites, throat cultures, a nose culture and an abscess in an eyelid. ${ }^{2}{ }^{8}$ However, in these cases either clinical information is not given or the pathogenicity of the organism is in doubt. Although 21 of the 75 isolates of Kingella kingae held at the Center for Disease Control have as their source bone- or joint-associated sites, ${ }^{2}$ the pathogenic role of this species in bone or joint infections does not appear to have been documented. We could find no reports of osteomyelitis associated with Kingella spp or Moraxella spp, and only two recorded cases of septic arthritis associated with Moraxella spp .1112 A third and more recent report on the identification of a Moraxella sp from infectious arthritis in an adult ${ }^{13}$ was based on inadequate criteria and the inappropriate use of the API 20E system in the characterisation of a fastidious Gramnegative diplococcus. The three cases reported here are of interest because, in each case, the isolation of Kingella kingae in pure culture indicates the organism's probable pathogenic role in the infection. Apart from the age of patient 1 and the possibility of previous injury to the hip of patient 3 , there appear to have been no conditions in the patients described that would have predisposed them to infection. It is likely that the bacterium was spread from its normal site by a haematogenous route to the bone or joint.

Kingella kingae was originally described as a species of Moraxella, and its microscopic appearance, fastidious growth requirements, positive oxidase reaction and sensitivity to penicillin are characteristic of that genus. It may be distinguished from Moraxella spp, however, by its negative catalase reaction and its saccharolytic activity. Two other Gram-negative rod-shaped organisms, Eikenella corrodens and Cardiobacterium hominis, share the fastidious growth requirements of Kingella kingae as well as its unusual combination of positive oxidase and negative catalase reactions. Characteristics for distinguishing Kingella kingae from these two species as well as from Moraxella spp, Branhamella spp, and other members of the Kingella genus, have been described by Snell and Lapage. ${ }^{14}$

Kingella kingae is not commonly encountered in clinical specimens and may be unfamiliar to many laboratory workers. The cases reported indicate the need to consider this organism as a possible pathogen in bone and joint infections.

\section{Addendum}

We have recently noted a letter (Redfield DC et al. Arch Dis Child 1980;55:411) reporting the isolation of Kingella kingae from the blood of a leukaemic child with skin lesions and arthritis of the left knee.

We are grateful to $\mathrm{Mr} \mathrm{W}$ Huffam of the Geelong District Hospital, Geelong, and Mr A Woodward and $\mathrm{Mr} \mathrm{M}$ Menelaus of the Royal Children's Hospital, Melbourne, who kindly provided us with the clinical information that made this paper possible. We also thank Ms J Banks of the Geelong District Hospital and Mr A Hewstone and Miss M Ritchie of the Royal Children's Hospital for their valuable help.

\section{References}

${ }^{1}$ Henriksen SD, Bøvre K. Moraxella kingii sp nov, a haemolytic, saccharolytic species of the genus Moraxella. J Gen Microbiol 1968;51:377-85.

${ }^{2}$ Weaver RE, Hollis DG. Gram-negative fermentative bacteria and Francisella tularensis. In: Lennette EH, Balows A, Hausler WJ Jr, Truant JP, eds. Manual of slinical microbiology. 3rd ed. Washington DC: American Society for Microbiology, 1980:253.

${ }^{3}$ Bøvre K, Henriksen SD, Jonsson V. Correction of the specific epithet kingii in the combinations Moraxella kingii Henriksen and Bøvre 1968 and Pseudomonas 
kingii Jonsson 1970 to kingae. Int J Syst Bacteriol 1974; 24:307.

${ }^{4}$ Henriksen SD, Bøvre K. Transfer of Moraxella kingae Henriksen and Bøvre to the genus Kingella gen nov in the family Neisseriaceae. Int J Syst Bacteriol 1976;26:447-50.

- Cowan ST, Steel KJ. In: Cowan ST, ed. Manual for the identification of medical bacteria. 2nd ed. London: Cambridge University Press, 1974.

- Bøvre K, Henriksen SD. Minimal standards for description of new taxa within the genera Moraxella and Acinetobacter: proposal by the subcommittee on Moraxella and allied bacteria. Int J Syst Bacteriol 1976;26:92-6.

${ }^{7}$ Bell SM. The CDS disc method of antibiotic sensitivity testing (Calibrated Dichotomous Sensitivity test). Pathology 1975;7 suppl:1-48.

${ }^{8}$ Henriksen SD. Corroding bacteria from the respiratory tract. 1. Moraxella kingii. Acta Pathol Microbiol Scand $1969 ; 75: 85-90$.

- Christensen CE, Emmanouilides GC. Bacterial endocarditis due to "Moraxella new species I". $N$ Engl J Med
1967;277:803-4.

${ }^{10}$ Miridjanian A, Berrett D. Infective endocarditis caused by Moraxella kingae. West J Med 1978;129:344-6.

${ }^{11}$ Feigin RD, San Joaquin V, Middelkamp JN. Septic arthritis due to Moraxella osloensis. J Pediatr 1969;75: 116-7.

${ }^{12}$ Spahr RC. Septic arthritis due to Moraxella species. $J$ Pediatr 1975;86:310.

${ }^{13}$ Rosenbaum J, Lieberman DH, Katz WA. Moraxella infectious arthritis: first report in an adult. Ann Rheum Dis 1980;39:184-5.

${ }^{14}$ Snell JJS, Lapage SP. Transfer of some saccharolytic Moraxella species to Kingella Henriksen and Bøvre 1976, with descriptions of Kingella indologenes sp nov and Kingella denitrificans sp nov. Int J Syst Bacteriol 1976;26: 451-8.

Requests for reprints to: Ms JM Davis, Microbiological Diagnostic Unit, University of Melbourne, Parkville, Victoria 3052, Australia.

\section{Reports and Bulletins prepared by the Association of Clinical Biochemists}

The following reports and bulletins are published by the Association of Clinical Biochemists. They may be obtained from The Publishing Department, British Medical Journal (ACB Technical Bulletins), BMA House, Tavistock Square, London WC1H 9JR. Overseas readers should remit by British Postal or Money Order.

SCIENTIFIC REVIEWS (price $£ 1 \cdot 00 / \$ 2.00$ each)

1 The assessment of thyroid function March 1971 FV FLYNN and JR HOBBS

2 Renal function tests suitable for clinical practice January 1972 FL MITCHELL, N VEALL, and RWE WATTS

3 Biochemical tests for the assessment of fetoplacental function May 1975 CE WILDE and RE OAKEY

4 Test of exocrine pancreatic function March 1977 AH GOWENLOCK

5 Assay of cholinesterase in clinical chemistry March 1979 ELSIE SILK, J KING, and MARY WHITTAKER

\section{TECHNICAL BULLETINS (price $£ 1 \cdot 00 / \$ 2.00$ each)}

22 Bilirubin standards and the determination of bilirubin by manual and technicon AutoAnalyzer methods January 1971 BARBARA BILLING, RUTH HASLAM, and N WALD

23 Interchangeable cells for spectrophotometers and fluorimeters September 1971 ss BROWN and AH GOWENLOCK

24 Simple tests to detect poisons March 1972 BW MEADE $\boldsymbol{e}$ t al.

25 Blood gas analysers May 1972 K DIxoN

26 Kits for enzyme activity determination September 1972 SB ROSALKI and D TARLOW

27 Assessment of pumps suitable for incorporation into existing continuous flow analytical systems November 1972 A FLECK $e t$ al.

28 Routine clinical measurements of transferrin in human serum September 1973 K DIXON
29 Control materials for clinical biochemistry (5th edition) September 1973 JF STEVENS

30 Notes on the quality of performance of serum cholesterol assays September 1973 SS BROWN

31 Determination of uric acid in blood and in urine July 1974 RWE WATTS

32 A survey of amino acid analysers readily available in the United Kingdom September 1974 JE CARLYLE and P PURKISS

33 Definitions of some words and terms used in automated analysis November 1974 A FLECK, R ROBINSON, SS BROWN, and JR HOBBS

34 Measurement of albumin in the sera of patients January 1975 LINDA SLATER, PM CARTER, and JR HOBBS 35 Investigation of the validity of temperature correction factors for serum aspartate and alanine transaminases March 1975 SB ROSALKI $e t$ al.

36 Factors influencing the assay of creatinine November 1975 JGH COOK

37 A survey of enzyme reaction rate analysers readily available in the United Kingdom July 1977 RA SAUNDERS and RF BURNS

38 Transport of specimens for clinical chemistry analysis November 1977 P WILDING, JF ZILVA, and CE WILDE

39 A scheme for the evaluation of diagnostic kits May 1978 PH LLOYD

40 A practical guide to gamma-counting in radioimmunoassay January 1980 CE WILDE and D OTTEWELL 41 The use of biochemical tests in the diagnosis of disorders of calcium metabolism July 1980 ANGELA FAIRNEY 